\title{
CYSTIC ENDOMETRIAL HYPERPLASIA PADA KUCING DOMESTIK
}

\author{
Muhammad Noor Rahman ${ }^{*}$, Felician Lestari Wongkar², Rosalia Sin Baba², Sesilia Gredita Tani², \\ Roberto Y.L. ${ }^{2}$, Fajar Agung Panjalu², Benny Amirio Hadi ${ }^{2}$ \\ ${ }^{1}$ Fakultas Kedokteran Hewan, Universitas Wijaya Kusuma Surabaya \\ ${ }^{2}$ Mahasiswa PPDH Fakultas Kedokteran Hewan, Universitas Wijaya Kusuma Surabaya \\ email : drh.rahmen@gmail.com
}

\begin{abstract}
Abstrak
Kucing domestic berjenis kelamin betina berumur 3,5 tahun menunjukkan gejala klinis mengeluarkan cairan keruh kental pada vulva. Pada pemeriksaan fisik menunjukkan pembesaran abdomen, ketika dipalpasi teraba adanya benjolan dan kucing merespon adanya rasa sakit. Hasil USG menunjukaan ekogenitas hipoecoiqe dengan adanya acoustic enhancement yang berarti adanya organ berlumen yang beisi cairan. Sedangkan pada pemeriksaan X-Ray menunjukkan adanya bentukan yang opasitasnya intermediet pada organ uterus yang melebihi opasitas intermediet dari jaringan lemak. Hasil pemeriksaan hematologi menunjukkan hasil yang normal. Tindakan operasi yang dilakukan yaitu ovariohysterectomy. Dari hasil operasi ditemukan bentukan uterus yang diangkat mengalami penebalan dan adanya bentukan cystic. Sehingga diagnosa penyakit ini adalah Cystic Endometrial Hyperplasia. Tindakan terapi yang dilakukan yaitu amoxicillin, asam mefenamat, vitamin $\mathrm{B}$ dan vitamin $\mathrm{C}$ yang diberikan sehari dua kali selama lima hari. Setelah hari ke tujuh, luka insisi sudah kering dan kucing telah sehat dan makan dengan banyak.
\end{abstract}

Keywords: kucing, cystic endometrial hyperplasia

\section{PENDAHULUAN}

Kucing mempunyai daya tarik tersendiri karena bentuk tubuh, mata dan warna bulu yang beraneka ragam dengankelebihankelebihan tersebut maka kucing dapat dikembangbiakan dan dibudidayakan (Mariandayani, 2012). Salah satu penyakit yang bisa terjadi pada saluran reproduksi kucing adalah Cystic endometrial hyperplasia-pyometra kompleks (CEHpyometra kompleks). CEH-pyometra kompleks adalah penyakit yang ditandai dengan hiperplasia endometrium, diikuti dengan dilatasi kista kelenjar endometrium dan akumulasi eksudat yang mengandung banyak neutrofil dalam lumen uterus (Hollinshead, 2015).

Organ reproduksi betina terbagi dua, yaitu organ primer dan organ sekunder. Cystic endometrial hyperplasia-pyometra kompleks (CEH-pyometra kompleks) adalah penyakit yang ditandai dengan hiperplasia endometrium, diikuti dengan dilatasi kista kelenjar endometrium dan akumulasi eksudat yang mengandung banyak neutrofil dalam lumen uterus (Hollinshead, 2015). Cystic endometrial hyperplasia (CEH) dapat menghasilkan kondisi mucometra, haematometra, hydrometra maupun pyometra. Terjadinya pyometra merupakan kelanjutan dari cystic endometrial hiperplasia (CEH) akibat induksi progesteron kronis (Tawfik, 2015). Kejadian CEH-Pyometra kompleks juga bisa disebabkan karena ketidakseimbangan hormon akibat dari terapi hormonal untuk mencegah kebuntingan (Aqudelo, 2005).

Umummya kelebihan hormon progesteron menyebabkan terjadinya penebalan pada dinding uterus, yang memicu timbulnya kista (cystic endometrial hyperplasia/CEH). Akibat pengaruh hormon testosteron, jaringan glandular menjadi kista, edema dan menebal. Sekresi yang berlebihan dan terakumulasi pada lumen uterus, 
menjadikan lingkungan ideal untuk pertumbuhan bakteri. Kasus CEH-Pyometra kompleks disebabkan oleh adanya akumulasi nanah dalam lumen uterus kucing betina, penumpukan cairan nanah pada endometrium menyebabkan prostaglandin 2 alfa (PGF2 $\alpha$ ) tidak dihasilkan sehingga korpus luteum menjadi resisten dan tidak diregresi (Fossum et al.,2019).

Menurut Aqudelo (2005), CEHpyometra kompleks dikelompokkan kedalam beberapa tingkatan berdasarkan kondisi klinis, praklinis, dan histopatalogis. Ada 4 tipe CEH-Pyometra, yaitu: (1) Tipe $1 \mathrm{CEH}$ tanpa adanya proses inflamasi, tidak ada gejala klinis. (2) Tipe 2 CEH dengan endometritis akut. pada kebanyakan kasus terdapat corpus luteum. terdapat peningkatan nilai leukosit. gejala klinis bervariasi tergantung dari keparahan dan distensi uterus. (3) Tipe 3 Endometritis subakut dengan infiltrasi sel mononulear pada endometrium dan adanya sista pada kelenjar endometrium. Kenaikan jumlah sel darah putih sangat tinggi. gejala klinis lebih terlihat dibanding tipe 2. (4) Tipe 4 Endometritis kronis dengan atropi endometrium.

\section{MATERI METODE}

\section{Signalament}

\begin{tabular}{|l|l|}
\hline Nama & Jiso \\
\hline Jenis & kucing \\
\hline Tanda khusus & $\begin{array}{l}\text { perut membesar, } \\
\text { keluar cairan kental } \\
\text { dari vulva }\end{array}$ \\
\hline Ras & cat domestic \\
\hline Umur & $\pm 3,5$ tahun \\
\hline Berat badan & $5 \mathrm{~kg}$ \\
\hline Warna & kuning \\
\hline Jenis kelamin & betina \\
\hline
\end{tabular}

\section{Status present}

\begin{tabular}{|l|l|}
\hline Frekuensi nafas & \multicolumn{1}{|c|}{$48 \mathrm{x} /$ menit } \\
\hline $\begin{array}{l}\text { Frekuensi denyut } \\
\text { jantung }\end{array}$ & $128 \mathrm{x} /$ menit \\
\hline Temperatur & $38,9^{\circ} \mathrm{C}$ \\
\hline Gizi & baik \\
\hline Pertumbuhan badan & sangat baik \\
\hline
\end{tabular}

\begin{tabular}{|l|l|}
\hline Tempramen & agak garang \\
\hline Turgor kulit & baik \\
\hline Sikap badan & $\begin{array}{l}\text { berdiri dengan } \\
\text { empat kaki }\end{array}$ \\
\hline Selaput lendir & $\begin{array}{l}\text { Tidak ada } \\
\text { leleran }\end{array}$ \\
\hline
\end{tabular}

Berdasarkan pemeriksaan fisik, keadaan abnormal yang ditemukan yaitu, membesarnya abdomen, kucing menunjukkan rasa sakit saat dipalpasi. Keluarnya cairan kental keruh dari vulva.

\section{Hasil pemeriksaan USG}

Hasil USG menunjukaan ekogenitas hipoecoiqe dengan adanya acoustic enhancement yang berarti adanya organ berlumen yang beisi cairan.

\section{Hasil Pemeriksaan X-Ray}

Hasil pemeriksaan X-ray menunjukkan adanya opasitasnya intermediet yang melebihi opasitas intermediet dari jaringan lemak pada organ uterus

\section{Hasil Pemeriksaan Darah}

Tabel 1 Hasil pemeriksaan darah lengkap

\begin{tabular}{|l|l|l|l|}
\hline test & result & unit & $\begin{array}{l}\text { Reference } \\
\text { interval }\end{array}$ \\
\hline HCT & 30.4 & $\%$ & $24-55$ \\
\hline HGB & 9.5 & $\mathrm{~g} / \mathrm{dl}$ & $8-15$ \\
\hline MCM & 31.3 & $\mathrm{~g} / \mathrm{dl}$ & $30-36.9$ \\
\hline WBC & 17.6 & $\mathrm{~K} / \mu \mathrm{L}$ & $5-18.9$ \\
\hline GRANS & 11.1 & $10^{\wedge} 9 / \mathrm{L}$ & $2.5-12.5$ \\
\hline GRANS & 63 & $\%$ & \\
\hline L/M & 6.5 & $10^{\wedge} 9 / \mathrm{L}$ & $1.5-7.8$ \\
\hline L/M & 37 & $\%$ & \\
\hline PLT & 245 & $10^{\wedge} 9 / \mathrm{L}$ & $175-500$ \\
\hline Retic & & $\%$ & $0-1$ \\
\hline Fib & & $\mathrm{mg} / \mathrm{dL}$ & $50-300$ \\
\hline
\end{tabular}

Hasil pemeriksaan darah menunjukkan kucing dalam kondisi normal

\section{Tindakan Operasi}

Ovariohysterectomy

\section{Persiapan alat dan bahan operasi}


Alat-alat yang digunakan pada operasi ovariohisterectomy antara lain drape, perlengkapan operator (haircup, baju bedah, masker, sarung tangan), back house towel clamp, pinset anatomis dan pinset chirurgis, blade dan handle scalpel, klem arteri, needle dan needle holder, allis tissue forceps, gunting lurus tajam - tumpul, gunting metzenbaum bengkok, kasa steril, tampon, gurita.

Bahan- yang digunakan dalam operasi gstrotomi antara lain benang absorble (chromic dan plain) ukuran 3/0, benang non absorble (silk), air sabun, antiseptik (povidone iodine), atropine sulfat, acepromazine, ketamin, infus ringer lactat, vicillin, normal saline

\section{Tahapan operasi}

\section{Preoperasi}

Sebelumnya hewan dipuasakan selama \pm 6-12 jam sebelum operasi untuk menghindari keadaan vomit sebelumnya.

a. Hewan diberikan pre-anastesi

Atropine :

Atropine sulfat $=\mathrm{BB} \times$ dosis $/ \mathrm{kg} \mathrm{BB}$

$=5 \mathrm{~kg} \times 0,02 \mathrm{ml} / \mathrm{kg} \mathrm{BB}=0,1 \mathrm{ml}$

Acepromazine :

Acepromazine $=\mathrm{BB} \times$ dosis $/ \mathrm{kg} \mathrm{BB}$

$=5 \mathrm{~kg} \times 0,05 \mathrm{ml} / \mathrm{kg} \mathrm{BB}=0,25 \mathrm{ml}$

b. Hewan diberikan pembiusan dengan anestesi umum

\section{Ketamin :}

Ketamin $=\mathrm{BB} \times$ dosis $/ \mathrm{kg} \mathrm{BB}:$ sediaan

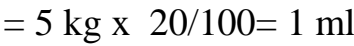

Premedikasi dilakukan dengan menginjeksi atropin (ATP) 0,1 ml yang sudah ditambahkan ACP 0,25 ml secara subcutan. Ditunggu hingga \pm 10 menit. Setelah itu dilakukan anestesi dengan ketamin $1 \mathrm{ml}$, di injeksikan secara intramuscular.

Pencukuran bulu hewan dilakukan 5-10 $\mathrm{cm}$ di sekitar bidang sayatan, (umbilikus kearah caudal) kemudian dicuci dengan air sabun dan dikeringkan dengan handuk.

\section{Teknik Operasi}

Pada daerah umbilicus ke caudal, dioleskan povidone iodine dahulu sebelum dilakukan insisi, kemudian dilakukan pemasangan drape pada daerah midline umbilicus caudal

Insisi dilakukan di daerah orientasi, yaitu pada daerah linea alba (laparotomi medianus) umbilicus kearah caudal. Kemudan dilakukan preparasi tumpul di bidang sayatan

Setelah rongga abdomen terbuka dilakukan pencarian uterus menggunakan spy hook. Kemudian cornua uterus diangkat dan dikeluarkan dari abdomen

Setelah ditemukan ovarium, dilakukan ligasi arteri ovarica menggunakan benang plain catgut kemudian potong arteri diantara dua klem. Setelah itu dilakukan pengecekan bahwa ligasi arteri sudah kuat dan tidak ada rembesan darah.

Selanjutnya dilakukan ligasi pada arteri uterine yang berada pada corpus uteri lalu insisi diantara kedua klam, dan dilanjutkan jahitan parker-ker karena lumen uterus yang cukup besar.

Keudian abdomen dibersihkan dengan menggunakan NS hingga bersih, dan setelah itu diberikan antibiotik vicillin

Peritonium dijahit menggunakan benang plain catgut dengan pola jahitan terputus sederhana

Kemudian lapisan subcutan dilakukan penjahitan dengan pola menerus sederhana dengan benang plain catgut

Penjahitan pada bagaian terakhir dilakukan pada kulit dengan jahitan terputus sederhana menggunakan benang silk.

Setelah jahitan selesai, kemudian diberikan povidone iodine dan ditutup dengan kassa steril dan ultrafix. Terapi post operasi yaitu Cefotaxime sodium $(0,1 \mathrm{ml} / \mathrm{kg}$ BB) dan Tolfedine $(0,1 \mathrm{ml} / \mathrm{kg} \mathrm{BB})$. 


\section{Perawatan Post Operasi}

Terapi post operasi diberikan obat oral selama lima hari yaitu amoxicilin (dosis $35 \mathrm{mg} / \mathrm{kgBB}$ ), asam mefenamat (dosis $15 \mathrm{mg} / \mathrm{kg} \mathrm{BB})$, vitamin $\mathrm{C}$ dan vitamin $\mathrm{B}$.
Luka insisi dilakukan pembersihan dan penggantian kasa perban setiap hari satu kali, dengan terapi topical yaitu betadine ${ }^{\circledR}$

\section{HASIL}

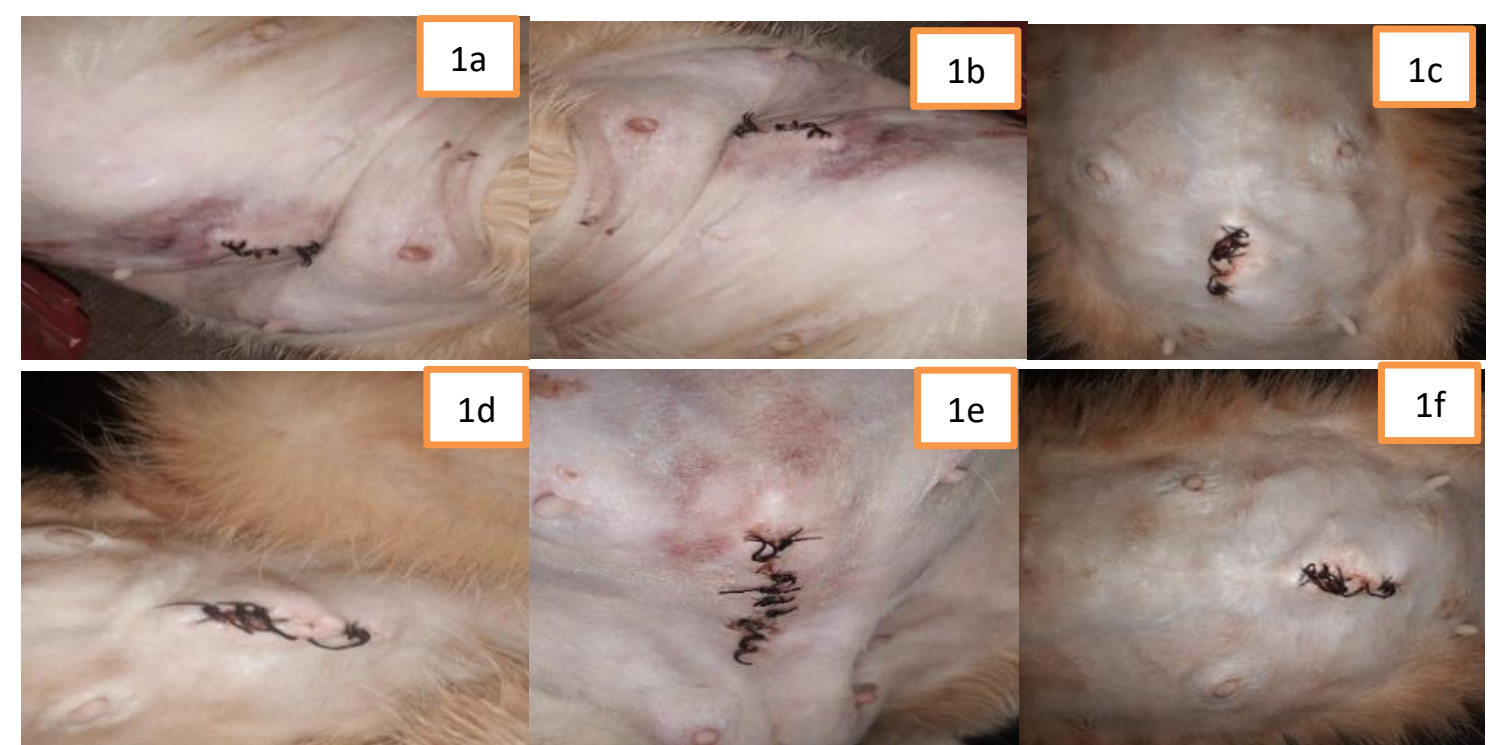

Gambar 1.a Harike-1 Luka masih basah; 1b. Hari ke-2 Luka masih basah dan bengkak; 1c. Hari ke-3 Luka sedikit basah dan membengkak;1d. Hari ke-4 Luka pada cranial masih basah dan Luka di cauda; mulai menutup,kering,pembengkakan masih terjadi; 1e. Hari ke-5 Luka mulai kering dan masih bengkak; 1f. Hari ke-6 Luka mulai kering dan masih sedikit bengkak

\section{PEMBAHASAN}

Kucing jiso ditemukan di pasar Mangga Dua pada hari Sabtu tanggal 13 Februari 2021 dengan kondisi kucing jiso perut membesar dan ketika dipalpasi terasa adanya benjolan dan kucing jiso merespon adanya rasa sakit ketika dipalpasi. Dan ketika di perhatikan pada daerah vulva terdapat leleran berwana keruh yang keluar.
Dugaan awal menurut gejala klinis adalah maserasi fetus atau Pyometra.

Pada hari minggu tanggal 14 januari 2021 dilakukan pemeriksaan penunjang yaitu pemeriksaan X-Ray, dengan hasil adanya bentukan yang opasitasnya intermediet yang melebihi opasitas intermediet dari jaringan lemak. 


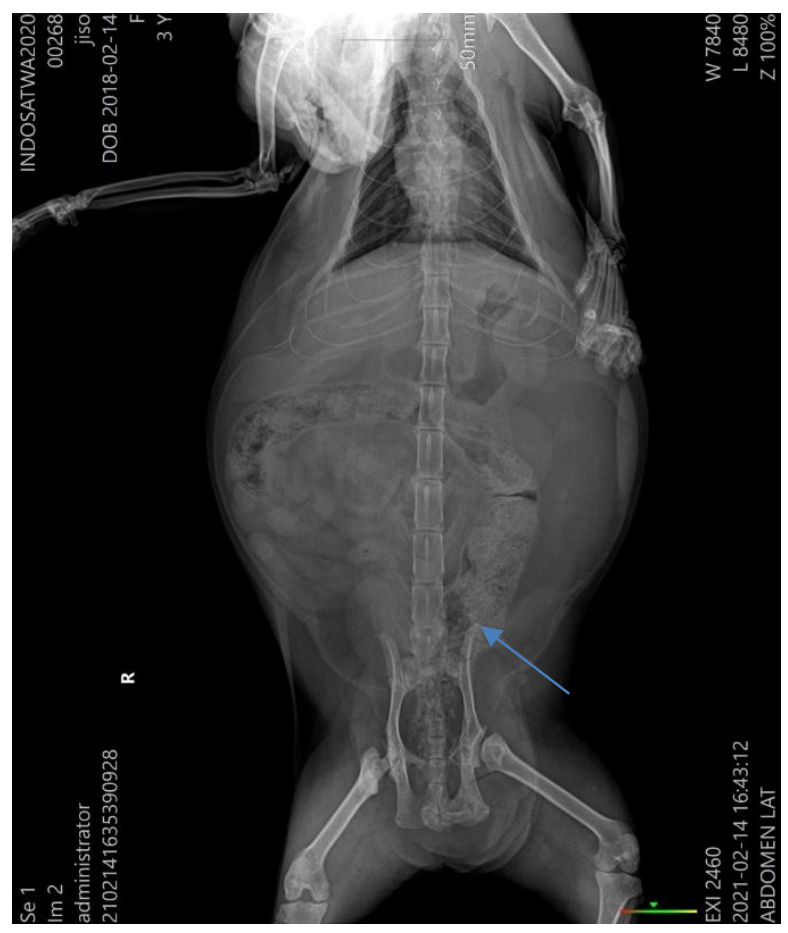

\section{Gambar 2. hasil X-Ray Abdominal Ventrodosal kucing Jiso}

Pada hari senin tanggal 15 Februari 2021, dilanjutkan pemeriksaan penjunjang yaitu USG dan test darah lengkap. Hasil USG menunjukaan ekogenitas hipoecoiqe dengan adanya acoustic enhancement yang berarti adanya organ berlumen yang beisi cairan.

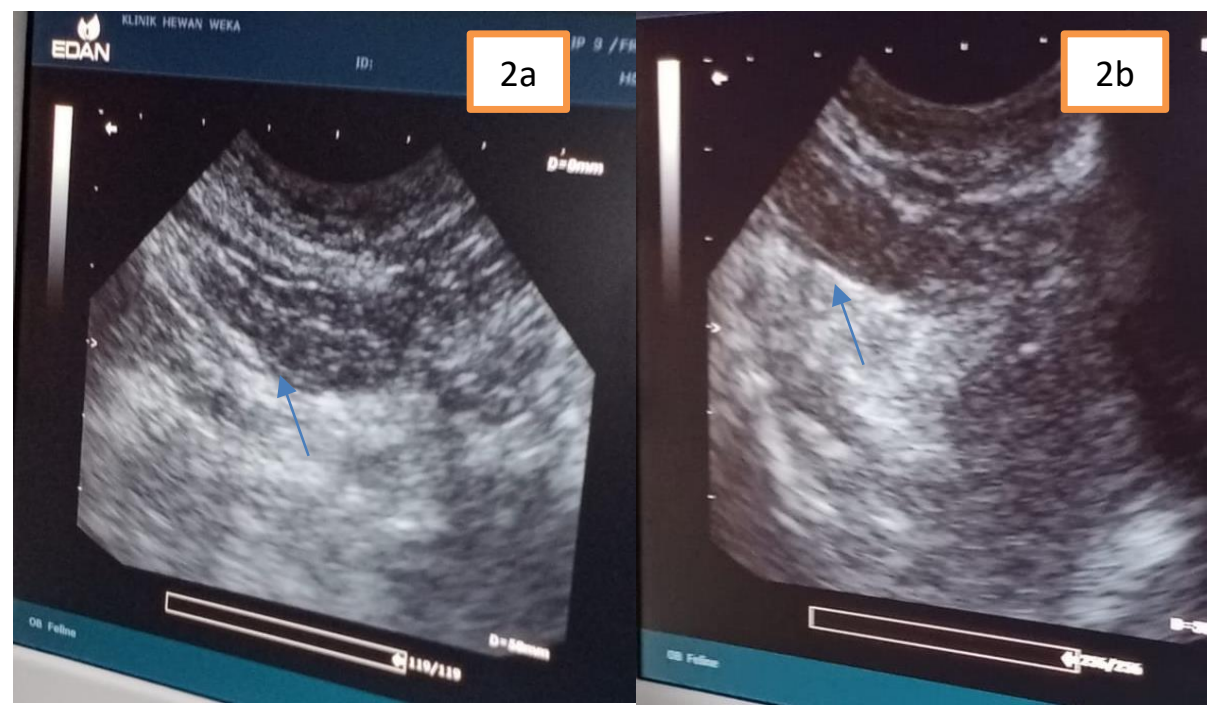

Gambar 2a. hasil USG Uterus Kiri; 2b. Hasil USG Uterus Kanan

Untuk hasil darah lengkap tidak terjadi perubahan pada komponen darah (normal) yang berarti kucing masih dalam kondisi normal dalam artian tidak terjadi inflamasi pada tubuh kucing. Sehingga dugaan pyometra belum bisa dipastikan. Dari data pemeriksaan penunjang diatas, kasus kucing jiso mengarah pada penyakit cystic 
endometrial hyperplasia-Pyometra Type 1, karna kucing belum mengalami inflamasi dan belum menunjukkan gejala klinis yang khas.

Tanggal 16 Februari 2021, dilakukan operasi Ovario-Hysterectomy pada kucing jiso, dan hasil yang ditemukan ditunjukkan pada gambar 4.

Dari hasil operasi, ditemukan penebalan uterus yang sesuai dengan hasil USG yaitu uterus yang hypoecoiqe menunjukkan lumen uterus tidak isi pus (nanah), melainkan terjadinya penebalan dinding uterus dan ditemukan adanya cystic uterus. Dan hal ini juga sesuai dengan hasil pengujian darah yang menunjukkan hasil yang normal dimana sesuai dengan hasil operasi uterus tidak terdapat akumulasi pus (nanah) yang berarti belum terjadi inflamasi.

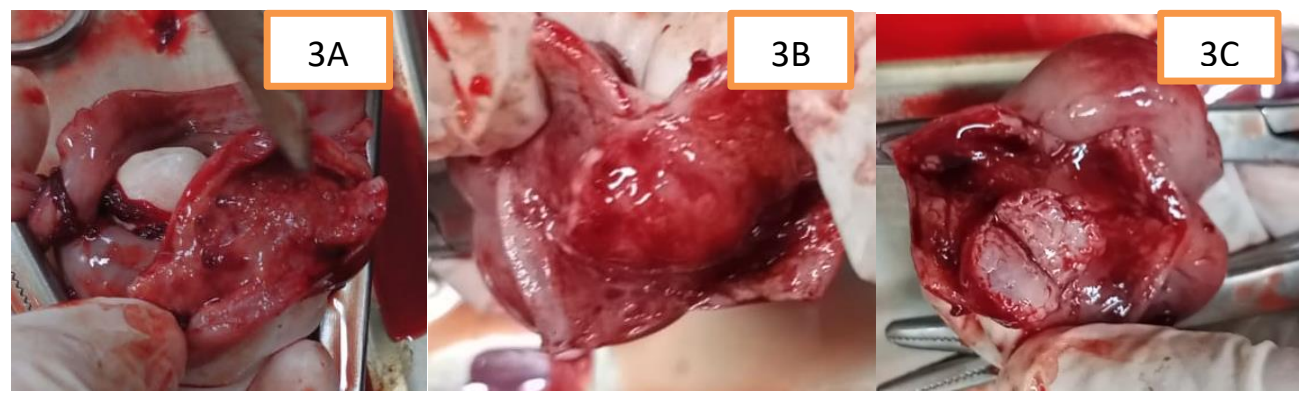

Gambar 3A. foto dinding uterus ditemukan bentukan bintik-bintik; 3B. adanya benjolan pada dinding uterus; $3 \mathrm{C}$. benjolan pada uterus setelah diinsisi.

\section{KESIMPULAN}

Berdasarkan hasil pemeriksaan X-Ray, USG dan Pemeriksaan darah lengkap serta kondisi uterus pasca operasi. Kucing Jiso dapat didiagnosa Cystic Endometrial Hyperplasia

\section{REFERENSI}

Aqudelo CF. 2005. Cystic Endometrial Hyperplasia Pyometra Complex in Cats. A review. The Veterinary Quarterly. 27(4): 173-182.

Fossum, T. W., Cho, J., Dewey, C. W., Hayashi, K., Huntingford, J. L., MacPhail, C. M., et al. 2019. Small Animal Surgery, 5th Edition. Elsevier Inc. Philadelphia.
Hollinshead, F. 2015. Pyometra in The Queen. CVE Control \& Therapy SeriesIssue 278March. Sydney. C\&T Publising. pp: 27-29

Mariandayani, H.N. 2012. Keragaman kucing dopmestic (Felis domesticus) Berdasarkan Morfogenetik. Jurnal peternakan sriwijaya Vol 1 no 1 . Hal. $10,11,3$.

Tawfik MF, Oda SS, El-Neweshy MS, ElManakhly ESM. 2015. Pathological Study on Female Reproductive Affections in Dogs and Cats at Alexandria Province, Egypt. Alexandria Journal of Veterinary Sciences. 46: 74-82. 
e-ISSN 2685-8894; p-ISSN 2460-9773

Jurnal Vitek Bidang Kedokteran Hewan Vol.11 No.1, Mei 2021 